\title{
P-43 BENTHIC FORAMINIFERA ASSEMBLAGE IN ADRIATIC SEA POCKMARK
}

G. PANIERI, G. GABBIANELLI and S. D'ONOFRIO
Bologna University, Dipartimento di Scienze della Terra e Geo-Ambientali, Via Zamboni 67, 40126 Bologna, italy

\begin{abstract}
One field of pockmarks (Bonaccia Field located at $43^{\circ} 35^{\prime} \mathrm{N}$ and $14^{\circ} 22^{\prime} \mathrm{E}$, ca $35 \mathrm{Km} \mathrm{SE}$ offshore of the Conero Promontory) was explored in the central Adriatic Sea with the aim to recover cores utilized to investigate the effects due to the presence of gas on benthic foraminifera assemblage.
\end{abstract}

The purpose of this paper is to provide a micropaleontological characterization of the sediments influenced by methane presence. With this aim three Kullenberg cores ( $c a 1$ meter length) were recovered respectively in correspondence of a mud-volcano in the centre of one pockmark (GAB2) (Fig. 2), in the pockmark bottom (GAB1) and in the nearby continental shelf (GAB3) (Fig.1).

The Bonaccia Field area had been previously explored with high resolution reflection seismic method, thus providing a base map. Pockmarks, mud-volcanoes and carbonate concretions were detected in the area and testifying gas rising. One pockmark was particularly interesting because in the centre area a little mud volcano has been recognized. The pockmark is a semi-elliptical ( $100 \mathrm{~m}$ by $70 \mathrm{~m}$ ) flat depression and it is interpreted as caused by gas rising to the surface. The pockmark is located in an area characterized by thin sandy deposits called relict sands deposed during Versilian Transgression (10 ky B.P.) and Holocenic mud belt (Van Straaten, 1970; Colantoni et al., 1979) deposited during an high-standing system tract (Trincardi et al., 1994). The Holocenic mud belt are diffusely impregnated by biogenic gas, mainly methane. There are weak evidences of surface manifestation of mud extrusion consists of creep and slumping (Cita et al., 1981) that may produce reworked sediments, mud flows (Henry et al., 1990) and slope landslide (Prior et al., 1989). The sub-bottom of this profile presents sediment diffusely charged of gas rising locally (Fig. 2). The seismic profile interpretation reveals sandy silts sediment layer (2-5 $\mathrm{m}$ thick) lying over lens of peat and clay of continental or transitional environments. Physical proprieties of this gas-charged sediments show that the pores in the fine-grained sediment are partially filled with pore water and free gas. The amount of gas is assumed to be low and it is contained in the sediment as millimetre scale bubble: to this reason a significant reworking has not been seen.

The dominant lithology is essentially sandy clay and shell fragments; the fragments are composed by specimens broken and sometimes filled of Lamellibranchia, marine and fresh water Gastropods, Pteropods; Spatangoids, Ostracods, Bryozoans, Oogonia of Characeae and Otoliths.

A detailed study (qualitative and quantitative) of benthic foraminiferal assemblages of the three cores was performed with the aim to investigate this particular scenario. The inferred linkages are based on variation in benthic foraminiferal difference and stable isotopic signatures. Few

EAGE Conference on Geology and Petroleum Geology - St. Julians, Malta, 1 - 4 October 2000 
modern data exist to evaluate the hydrocarbon influence on the faunal and geochemical characteristics of benthic foraminiferal assembläge (Sen Gupta êt al., 1994; 1997; Rathburn et al., 2000). The following documentation is based on preliminary work, which is part of an ongoing study of the fossil and modern microfauna in hydrocarbon environments on Adriatic Sea.

Previously, a paleoenvironmental observation has been made considering the trend of the benthic species. The microfaunistic assemblage qualitative composition is similar in the three cores while variations frequency of some species has been noted.

The higher frequency of Protelphidium spp. and Ammonia spp. it was noted in the lower part of the cores GAB2 and GAB3, suggesting a lagoon environment of sedimentation. The assemblages of benthic foraminifera identified in the three cores in the upward sediments are instead characterized by normal marine environment taxa.

The communities of benthic foraminifers in GAB2 are characterized by some features that could be explained considering methane release in the past and present. Taking into account the assemblages in the entire core we have observed:

- lower microfaunistic diversity; perhaps only a small population of certain species could survive under ecological stress due to the presence of gas. For this reason, the individuals present belonging to stress environmental species (e.g. Bulimina spp., Cassidulina carinata) that support an environment with low quantity of oxygen and in some cases adapt to facultative anaerobes preference (Sen Gupta et al., 1997);

- lower abundance of benthic foraminiferal assemblage. Particularly, in some sample of GAB2 we have counted half number of benthic individuals in one gram of dry sediment respect to other sample of GAB1 and GAB3. The abundance of foraminiferal assemblage in surface samples showed variability, although all sampling stations were within a very small area and within the narrow depth range;

- high abundance of Rotaliida;

- higher abundance of epifaunal morphotype (Anomalinidae, Cassidulinidae, Elphidiidae) living on the sediment-water interface, than infaunal morphotype living within the sediment.

The evidences above mentioned could suggest that the presence of gas could transform sea-floor sediments into anomalous habitats for benthic foraminifera. This not prevent the benthic foraminifera life even if may be assumed that under ecological stress the benthic assemblages show different behaviors, according to Kaminski (1988) and Jones (1993), who note similar characteristics in some sites of Gulf of Mexico and North Sea.

Stable carbon analyses performed on calcitic benthic foraminiferal tests collected in GAB2, the core drilled in correspondence of the little volcanoes, have permitted to obtain interesting results. Some calcite tests of Ammonia, found at the base of GAB2 core, are extremely light in their carbon isotope composition. Calcite tests of Gavelinopsis analysed, collected in some samples of the core $\mathrm{GAB} 2$, show a broad range of $\delta^{13} \mathrm{C}$ values. The range of carbon isotope values shows differences up to $7 \% 0 \mathrm{ca}$, and shows more depleted values upward. Assuming that the isotopic values of benthic foraminifera reflect the environment conditions, we could interpret changes in values as different steps of methane seepages.

The anomalous of benthic foraminiferal tests values respect to those in normal marine environment calcite tests could be explained in terms of calcite precipitation within an isotopically altered microenvironment. Foraminifera deposit their calcite tests in isotopic 
equilibrium with the bottom water and their geochemistry carbonate is a function of pore-water chemistry and vital effects.

Quantity of methane reaching the oxic environment near the sediment-water interface could decrease the $\delta{ }^{13} \mathrm{C}$ of bicarbonate and dissolved inorganic carbon in near-surface pore waters. Wefer et al. (1994) purposed that benthic foraminiferal carbonate tests secreted in seepages area show more negative $\delta^{13} \mathrm{C}$ values compared to those from non-seep sites.

Few studies that examined benthic foraminifera associated with seeps (Sen Gupta et al., 1994; 1997; Rathburn et al., 2000) suggest that the isotopic composition of microenvironment could be recorded in isotopic composition of benthic foraminifera.

These preliminary results indicate that the isotopic signatures of benthic foraminifera could give indications of methane release in modern environment and in geologic record even if without additional data the interpretation remain speculative.

Acknowledgments: We would like to thank T. Ricchiuto and Eni - Agip Division for some isotopic measurement.

\section{References}

Cita M.B., Ryan W.F.B., Paggi L., 1981-Prometheus mud-breccia: An example of shale diapirism in the Western Mediterranean Ridge. Ann. Géol. Pays Hellén., 30: 543-570.

Colantoni P., Gallignani P. And Lenaz R., 1979-Late Pleistocene and Holocene evolution of the north Adriatic continental shelf. Marine Geology, 33: M41-M50.

Henry P., Le Pichon X., Lallemant S., Foucher J.P., Westbrook G., Hobart M., 1990-Mud volcano field seaward of the Barbados accretionary complex: A deep-towed side scan sonar survey. Journ. Geophys. Res., 95, B6: 8917-8929.

Jones R.W., 1993-Preliminary observations on benthic foraminifera associated with biogenic gas seep in the North Sea. In: Applied Micropaleontology, Ed. David Graham Jenkins. Kluwer Academic Publishers, 69-80.

Kaminski M.A., 1988-Cenozoic Deep-Water Agglutinated Foraminifera in the North Atlantic. Unpublished Doctoral Dissertation, Massachusetts Institute of Technology/Woods Hole Oceanographic Institution.

Prior D.B, Doyle E.H., Kaluza M.J., 1989-Evidence for sediment eruption on deep sea floor, Gulf of Mexico. Science, 243: 517-519.

Rathburn A.E., Levin L.A., Held Z., Lohmann K.C., 2000-Benthic foraminifera associated with cold methane seeps on the northern California margin: Ecology and stable isotopic composition. Marine Micropaleontology, 38: 247-266.

Sen Gupta B.K., Aharon P., 1994-Benthic Foraminifera of bathyal hydrocarbon vents of the Gulf of Mexico: Initial report on communities and stable isotopes. Geo-Marine Letters, 14: 88-96.

Sen Gupta B.K., Platon E., Bernhard J.M., Aharon P., 1997-Foraminiferal colonization of hydrocarbon-seep bacterial mats and underlying sediment, Gulf of Mexico slope. Journal of Foraminiferal Research, 27 (4): 292-300.

Trincardi F., Correggiari A., Roveri M., 1994-Quaternary transgressive erosion and deposition in a modern epicontinental shelf: the Adriatic Semienclosed Basin. Geo-Marine Letters, 14: 41-51.

Van Straaten L. M. J. U., 1970-Holocene and late-Pleistocene sedimentation in the Adriatic Sea. Geologische Rundschau, 60: 106-131. 
Wefer G, Heinze P.-M., Berger W.H., 1994-Clues to ancient methane release. Nature, 369: 282.

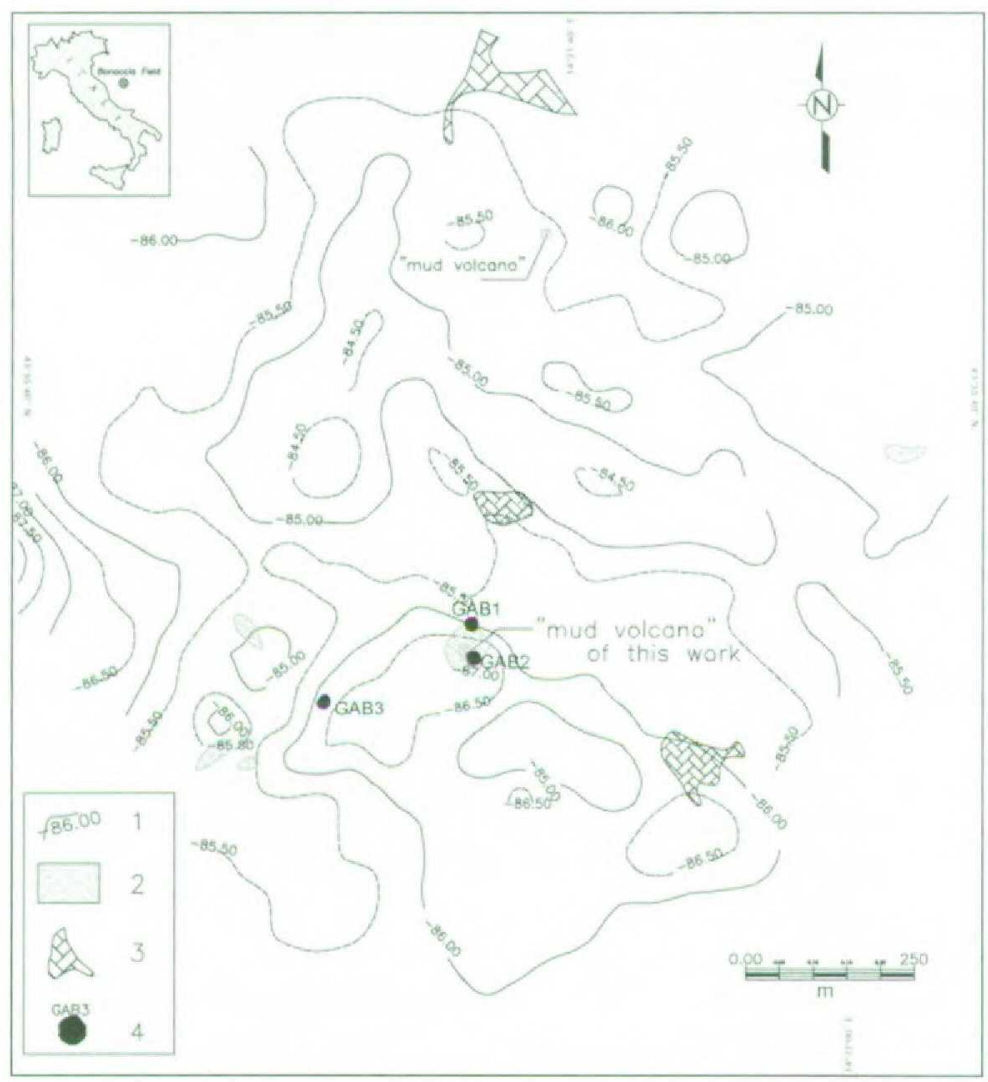

Captions:

1) Isobaths (0,5 $\mathrm{m}$ interval);

2) Coarse biogenic sediments;

3) Hard bottom, carbonates concretions;

4) Gravity cores location.

Fig. 1 - Bathymetric map of the Bonaccia area (Central Adriatic Sea, Italy).

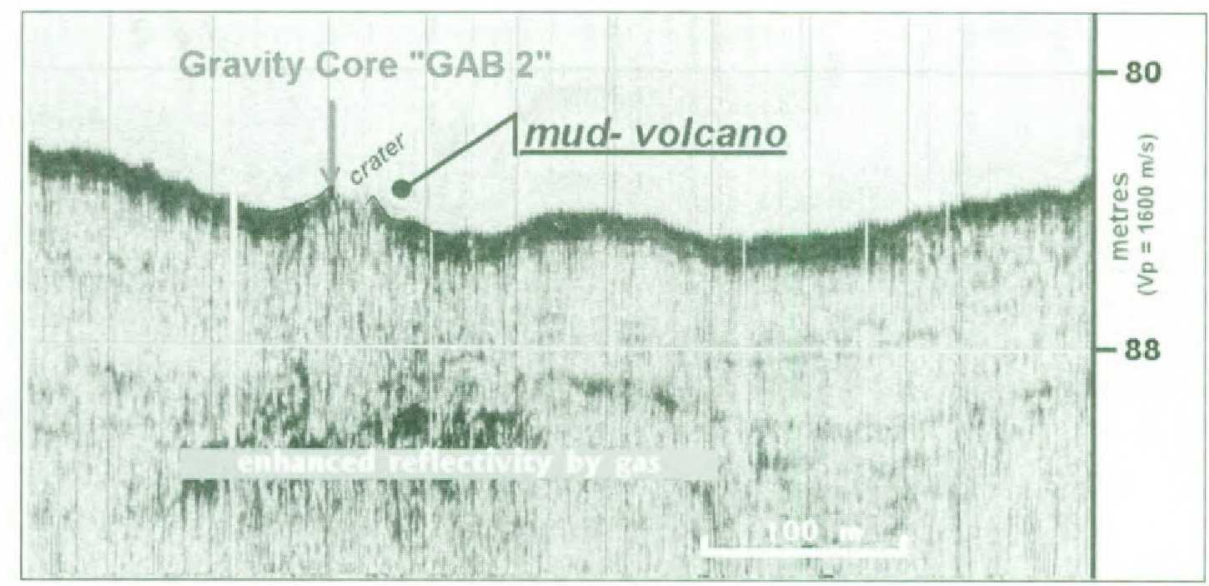

Fig. 2 - Details of a $3.5 \mathrm{kHz}$ sub-bottom profiles showing the volcano with rising gas detected in Bonaccia field. See location in Fig. 1. 